\title{
THE ROLE OF OXIDATIVE STRESS IN MENSTRUAL RELATED MIGRAINE
}

\author{
Hasibe ÖZGEÇEN DÍNÇEL*, Ayca ÖZKUL*, Ahmet ŞAİR*, Çiğdem YENISEY**, Ali AKYOL* \\ *Adnan Menderes University Faculty of Medicine, Department of Neurology, Aydın, TURKEY \\ **Adnan Menderes University, Faculty of Medicine, Department of Biochemistry, Aydın, TURKEY
}

\begin{abstract}
INTRODUCTION: Menstrually related migraine (MRM) is a headache disorder occurring in reproductive-aged women relevant to menstrual cycles. Attacks occur with decreases in estrogen and may be relevant to oxidative stress which hasn't been clear yet. Our aim was to investigate oxidative stress markers during menstrual cycle which may be important in pathophysiology of MRM as a vascular type headache.

METHODS: 20 patients with MRM (32.65 \pm 8.75 age) and 20 healthy volunteers $(30.25 \pm 8.6$ age $)$ were included in our study. All subjects were examined during an attack-free interval and blood samples were taken in order to study estrogen, progesteron, LH, FSH, nitric oxide (NO), malondialdehyde (MDA), superoxide dismutase (SOD) , glutathione (GSH) and glutathione reductase (GSH-Rd) in midfollicular and midluteal phases of the menstrual cycle.

RESULTS: There was no statistical significant difference between the control and the patient groups in according to age, menstrual cycle duration and hormones. GSH-Rd (62.96 \pm 17.22 vs $84.69 \pm 38.64, p=0.04)$ and SOD $(3834.44 \pm 1423.8$ vs $4562.41 \pm 1825.3, \mathrm{p}=0.003$ ) of MRM group were found elevated in the luteal phase when compared with follicular phase but this couldn't be detected in the control group.

DISCUSSION and CONCLUSION: Our results suggested that the antioxidant system in the follicular phase is inadequate relative to healthy subjects in MRM. The antioxidant defence system have to be taken into account to understand the pathophysiology of MRM and therefore need further studies.
\end{abstract}

Keywords: migraine, headache, menstruation, oxidative stress, estrogen.

\section{MENSTRUASYON İLIŞKILI MIGRENDE OKSIDATIF STRESIN ROLÜ}

\section{ÖZET}

GİRIȘ ve AMAÇ: Menstruasyon ilișkili migren (MIM) üreme çağı kadınlarda görülen menstruel siklus ile alakalı bașağrıSı bozukluğudur. Ataklar östrojenin düşmesi ile gelişir ve henüz netlik kazanmamakla birlikte oxidatif stres ile ilişkili olabilir. Amacımız oksidatif stres göstergelerini MìM ve sağlıklı kontrollerde menstrual siklus süresince incelemektir.

YÖNTEM ve GEREÇLER: MİM tanılı 20 hasta (32.65 \pm 8.75 yaș) ve 20 sağlıklı gönüllü (30.25 \pm 8.6 yaș) çalıșmaya alındı. Tüm katılanlar attaksız dönemde değerlendirildi ve kan örnekleri östrodiol, progesteron, LH, FSH, nitrik oksid (NO), malondialdehid (MDA), superoksid dismutaz (SOD) , glutatyon (GSH) ve glutatyon redüktaz (GSH-Rd) çalışılmak üzere menstrual siklusun midfolliküler ve midluteal fazlarında alındı.

BULGULAR: Kontrol ve hasta grubu arasında yaş, menstrual siklus süresi ve hormonlar açısından istatistiksel belirgin fark yoktu. MIM grubunun GSH-Rd $(62.96 \pm 17.22$ vs $84.69 \pm 38.64, \mathrm{p}=0.04)$ ve SOD $(3834.44 \pm 1423.8$ vs $4562.41 \pm 1825.3$, $\mathrm{p}=0.003$ ) değerleri luteal fazda folliküler faz ile kıyaslandığında artmış bulundu ancak bu kontrol grubunda izlenmedi. TARTIŞMA ve SONUÇ: Sonuçlarımız MIMM'de foliküler fazda antioksidan sistemin sağlıklı bireylere göre yetmezliğini desteklemektedir. Antioksidan savunma sistemi MIM patofizyolojisini anlamada ele alınmalıdır ve bu nedenle ileri çalışmalara ihtiyaç duyulmaktadır.

Anahtar Sözcükler: migren, bașağrısı, menstruasyon, oksidatif stres, östrojen.

Corresponding author: Ayça Özkul, Prof. MD. Adnan Menderes University, Faculty of Medicine, Department of Neurology, 09010 Aydın Turkey.

Telephone: +90 4441256 E-mail: ozkulayca@hotmail.com

Received: $10.06 .2018 \quad$ Accepted: 21.10 .2018

This article should be cited as following: Özgeçen Dinçel H, Özkul A, Şair A, Yenisey Ç, Akyol A. The role of oxidative stress in menstrual related migraine. Turkish Journal of Cerebrovascular Diseases 2018; 24 (3): 107-111. doi: 10.5505/tbdhd.2018.30502 


\section{INTRODUCTION}

Migraine is a prevalent headache disorder affecting three times more women than men during the reproductive years. In over half these women, their headaches are strictly related to their menstrual cycle $(1,2)$. Menstruation is a significant risk factor for migraine. Menstrually related migraine (MRM) is known with attacks most likely to occur on or between 2 days before the onset of menstruation and the first 3 days of bleeding cycle in at least two of three consecutive menstrual cycles. Additional migraine attacks with or without aura can occur at other times of the cycle $(2,3)$.

Among women with migraine, $11 \%$ have onset of migraine at menarche and are more likely to experience MRM. Approximately 60\% have migraine with menses and at other times during the menstrual cycle. The trigger for MRM attack is the drop in estrogen occurring during the late luteal phase of the menstrual cycle (4). Changes in multiple neurotransmitter systems occur with decreases in estrogen and are purported to be relevant to migraine attacks (5). The other possible mechanisms may be related to prostaglandin release, changes in opioid tonus, increased sensitivity of dopamine receptors and serotonergic transmission (6). The mechanism of how the estrogen decrease triggers migraine is not well understood. One of the possible mechanisms is oxidative stress. Geyik et al. found elevated 8hydroxy-2'-deoxyguanosine as an evidence of oxidative stress-related DNA damage in migraine (7).

In premenopausal women, one of the primary mechanisms of transient change of arterial reactivity is probably the change in the production of NO which causes vasodilation and oxidative stress that may trigger headache. In literature there are publications about oxidative stress patrameters in migraine patients, however there isn't any study examining oxidative stress during a menstrual cycle in MRM.

The aim of this study was to investigate oxidative stress markers including nitric oxide (NO), malondialdehyde (MDA), superoxide dismutase (SOD), glutathione (GSH) and glutathione reductase (GSH-Rd) changes during a menstrual cycle in patients with MRM. The results were compared with healthy controls.

\section{MATERIAL AND METHODS}

In our study, 20 patients with MRM (32.65 \pm 8.75 age) and 20 healthy volunteers (30.25 \pm 8.6 age) who admitted to our neurology headache polyclinic betwween January and September 2012 were included under informed consent conditions. Diagnosis of migraine type was made according to IHS- 2013 diagnosis criteria (2). Patients with hematologic, endocrinologic disorders, psychiatric illness, hypertension, dyslipidemia, infection, epilepsy, cerebrovascular disease, irregularities in menstrual cycle were all excluded. None of the participants had oral contraceptive use, smoking, migraine prophylaxis therapy, analgesics, alcohol and caffeine intake during in the last 48 hours. All patients were examined during an attack-free interval (at least 5 days after an attack).

The blood samples were taken during follicular (3-8 days of the menstrual cycle) and luteal (18-23 days of the menstrual cycle) phases of the hormonal cycle. Follicular and luteal NO, MDA, SOD, GSH and GSH-Rd blood levels were studied in all participants in order to evaluate oxidative stress. The study was approved by the local ethics committee of our university.

\section{Statistical analyses}

Statistical Package for the Social Sciences (SPSS) 14.0 (SPSS Inc., Chicago, IL, USA) was used for statistical analysis. Descriptive statistics were given as mean \pm standard deviation. We tested whether or not the variables which were detected in numeric scales in both groups had a normal distribution by using the Kolmogorov Smirnov test. All variables had normal distribution and parametric Independent Sample T test was used in statistical analysis. Data were analyzed using paired t-tests. Chi square tests were used to analyze categorical variables and $\mathrm{p}<0.05$ was considered statistically significant for all comparisons.

\section{RESULTS}

There was no statistical significant difference between the control and the patient groups in according to age and menstrual cycle duration. In comparison of hormones we found no significant difference between groups (Table I). The values of antioxidants, GSH-Rd $\quad(62.96 \pm 17.22 \quad$ vs $84.69 \pm 38.64, \mathrm{p}=0.04)$ and SOD $(3834.44 \pm 1423.8$ 
vs $4562.41 \pm 1825.3, p=0.003$ ) of MRM group increased significantly in the luteal phase when compared with follicular phase but this couldn't be detected in the control group (Table II).
Although follicular NO levels were higher than luteal levels in our control group $(26.73 \pm 11.1$ vs $22.14 \pm 11.7, p>0.05$ ), there was no statistically significancy (Table III).

Table I. Demographic characteristics and menstrual hormones of the groups studied showing no significant difference between groups.

\begin{tabular}{|c|c|c|c|c|}
\hline & & MRM $(n=20)$ & Control $(n=20)$ & $\mathrm{p}$ \\
\hline \multicolumn{2}{|l|}{ Age (year) } & $32.65 \pm 8.75$ & $30.25 \pm 8.6$ & NS \\
\hline \multicolumn{2}{|c|}{ Menstrual cycle length (day) } & $28.2 \pm 1.3$ & $28 \pm 0.7$ & NS \\
\hline \multirow[t]{8}{*}{ Hormones } & Estrodiol-F (pg/ml) & $57.23 \pm 24.82$ & $52.66 \pm 22.46$ & NS \\
\hline & Progesteron-F (ng/ml) & $0.53 \pm 0.19$ & $0.49 \pm 0.25$ & NS \\
\hline & LH-F (mIU/ml) & $5.65 \pm 4.27$ & $4.8 \pm 1.77$ & NS \\
\hline & FSH-F (mIU/ml) & $9.2 \pm 7.62$ & $7.66 \pm 4.43$ & NS \\
\hline & Estrogen-L (pg/ml) & $132.99 \pm 52.89$ & $127.46 \pm 45.97$ & NS \\
\hline & Progesteron-L(pg/ml) & $6.99 \pm 4.19$ & $6.46 \pm 3.9$ & NS \\
\hline & LH-L (mIU/ml) & $7.3 \pm 6.0$ & $6.07 \pm 4.7$ & NS \\
\hline & FSH-L $(\mathrm{mIU} / \mathrm{ml})$ & $4.08 \pm 2.68$ & $4.46 \pm 3.6$ & NS \\
\hline
\end{tabular}

Values are given as mean \pm standard deviation. $-\mathrm{F}$ : follicular , -L: luteal. NS: not significant $\mathrm{p}>0.05$

Table II. Comparison of oxidative stress parameters of MRM and controls showing no significant difference between groups.

\begin{tabular}{|c|c|c|c|c|c|}
\hline & MRM & Control & & & $\mathrm{p}$ \\
\hline $\mathrm{NO}-\mathrm{F}(\mu \mathrm{mol} / \mathrm{l})$ & $23.65 \pm 13.9$ & $26.73 \pm 10.4$ & -10.97 & 4.8 & NS \\
\hline NO-L $(\mu \mathrm{mol} / \mathrm{l})$ & $20.63 \pm 12.35$ & $22.14 \pm 11.72$ & -9.2 & 6.2 & NS \\
\hline GSH-F (mg/g Hb) & $3.04 \pm 0.57$ & $3.11 \pm 0.44$ & -0.39 & 0.26 & NS \\
\hline GSH-L (mg/g Hb) & $3.16 \pm 0.56$ & $3.10 \pm 0.49$ & -0.28 & 0.39 & NS \\
\hline GSH-Rd-F (U/g Hb) & $62.96 \pm 17.22$ & $67.66 \pm 34.09$ & -22.19 & 12.8 & NS \\
\hline GSH-Rd-L (U/g Hb) & $84.69 \pm 38.64$ & $65.75 \pm 29.6$ & -3.16 & 41.1 & NS \\
\hline MDA-F $(\mu \mathrm{mol} / \mathrm{l})$ & $11.73 \pm 2.9$ & $10.25 \pm 1.86$ & -0.09 & 3.07 & NS \\
\hline MDA-L ( $\mu \mathrm{mol} / \mathrm{l})$ & $12.20 \pm 3.1$ & $10.76 \pm 2.35$ & -0.34 & 3.2 & NS \\
\hline SOD-F (ng/g Hb) & $3834.43 \pm 1423.7$ & $3872.65 \pm 2115.6$ & -1197.9 & 1121.5 & NS \\
\hline SOD-L (ng/g Hb) & $4562.40 \pm 1825.3$ & $4020.96 \pm 1681.1$ & -582.12 & 1665 & NS \\
\hline
\end{tabular}

Values are given as mean \pm standard deviation. CI: Confidence interval. -F: follicular , -L: luteal. NS: not significant p>0.05

Table III. Comparison of oxidative stres parameters of follicular and luteal phases of MRM and control groups. GSH-Rd and SOD levels in MRM group were increased significantly in the luteal phase when compared with follicular phase but not in the control group.

\begin{tabular}{|c|c|c|c|c|c|c|c|c|}
\hline & \multicolumn{4}{|l|}{ MRM $(n=20)$} & \multicolumn{4}{|l|}{ Control $(n=20)$} \\
\hline & Follicular & Luteal & t-value & $\mathrm{p}$ & Follicular & Luteal & t-value & $\mathrm{p}$ \\
\hline $\mathrm{NO}(\mu \mathrm{mol} / \mathrm{l})$ & $23.65 \pm 13.9$ & $20.63 \pm 12.35$ & 1.65 & NS & $26.73 \pm 10.4$ & $22.14 \pm 11.72$ & 1.526 & NS \\
\hline GSH (mg/g Hb) & $3.04 \pm 0.57$ & $3.16 \pm 0.56$ & -1.48 & NS & $3.11 \pm 0.44$ & $3.10 \pm 0.49$ & 0.52 & NS \\
\hline GSH-Rd (U/gHb) & $62.96 \pm 17.22$ & $84.69 \pm 38.64$ & -2.24 & 0.037 & $67.66 \pm 34.09$ & $65.75 \pm 29.6$ & 0.201 & NS \\
\hline $\operatorname{MDA}(\mu \mathrm{mol} / \mathrm{l})$ & $11.73 \pm 2.9$ & $12.20 \pm 3.1$ & 0.668 & NS & $10.25 \pm 1.86$ & $10.76 \pm 2.35$ & -0.919 & NS \\
\hline SOD (ng/g Hb) & $3834.44 \pm 1423.8$ & $4562.41 \pm 1825.3$ & -2.98 & 0.008 & $3872.6 \pm 2115.6$ & $4020.9 \pm 1681.1$ & -0.437 & NS \\
\hline
\end{tabular}

Values are given as mean \pm standard deviation. CI: Confidence interval. -F: follicular , -L: luteal. NS: not significant p>0.05 


\section{DISCUSSION}

In our study we found that GSH-Rd and SOD levels were elevated in the luteal phase in migraine patients. This can be the result of the activated antioxidant defence system. GSH-Rd is a ubiquitous enzyme, which catalyzes the reduction of oxidized glutathione to GSH. It is essential for the glutathione redox cycle that maintains adequate levels of reduced cellular GSH which is a critical molecule in resisting oxidative stress and maintaining the reducing environment of the cell (8). GSH serves as an antioxidant, reacting with free radicals and organic peroxides, in amino acid transport, and as a substrate for the glutathione peroxidases and glutathione S-transferases in the detoxification of organic peroxides and metabolism of xenobiotics, respectively (8).

Superoxide anion is dismutated by superoxide dismutases (SODs) to hydrogenperoxide that is catalyzed to water by catalase, peroxiredoxins, or glutathione peroxidases. Similiar with GSH-Rd, SOD which is also a part of antioxidant defense system found elevated in luteal phase of mentrual cycle in MRM group. The elevation of GSH-Rd and SOD in the luteal phase couldn't be detected in control group. This may be the result of activated antioxidant defence system of MRM patients especially in luteal phase when migraine attacks mainly aggrevated. However, the same antioxidant defense system response couldn't be detected in controls.

Although Alp et al. recently found the decreased total antioxidants with an increase in the levels of total oxidants and the oxidative stress index in patients with migraine without aura (9), its relationship with hormones in MRM is still unknown. In literature there are limited data about the fluctuation of antioxidant enzymes in menstrual cycle. In a larger study fluctuations of GSH-Rd and SOD during menstrual cycle were studied but couldn't be detected in regularly menstruating women. However, in the same study it was shown that lower plasma estradiol concentrations resultant in attenuated erythrocyte SOD inhibition and elevated SOD enzyme activity (10). The exact mechanism of inhibitory estradiol action on SOD activity hasn't been clear yet and this needs further studies. The physiological response of antioxidant defence system to normal ovarian hormones especially estrogen cycle needs to be investigated especially in understanding the pathologies related to menstrual cycle like MRM. In our study GSH-Rd and SOD levels of control showed no significant difference during folliculer and luteal phases of the cycle which is concominant with literature $(10,11,12)$.

The drop in estrogen occurring during the late luteal phase of the menstrual cycle is accepted as a main reason for MRM attacks (13). It has been also shown in an invitro study that 17 betaestradiol increased membrane fluidity (a reciprocal value of membrane microviscosity) of erythrocytes and improved the rigidity of cell membranes in women through the NO and cGMP dependent mechanism (14). The mechanism of action of estrogen within the brain is related in part to the vascular system. Estrogen receptors were found in the endothelial and smooth muscle cells in the walls of brain arteries and arterioles (15). Stimulation of these receptors causes relaxation of the microvasculature following the secretion of a variety of vasoactive substances, such as NO (16), prostacyclin, and prostaglandin E2 $(17,18)$. All these data suggesting vasodilator effects of estrogen. In this study, follicular NO levels were higher than luteal levels in our control group, however there was no statistically significancy which limitted us to make a comment on this.

The altered sensitivity of estrogen receptors in the walls of brain arteries may cause MRM headaches. All these possible mechanisms have not been studied yet and they are the questions that need to be addressed in future studies.

There are also limitations of our study. Despite the fact that MRM patients without migraine attacks at folicular phase with regular menstruation cycle were not so common to be found, our study group wasn't so large. It would be better to have a larger group having more significant results. Additionally, subsequent analysis of studied parameters in different menstrual cycles may strengthed the value of our findings but it was almost impossible to design a study group having regular menstrual cycles with free migraine attacks in the following period, besides it was impossible to predict the next menstrual cycle. Additionally pure menstrually related migraine patients are study of interest. This can be also investigated in further studies with larger study groups. It can be concluded that the antioxidant system in the follicular phase was 
inadequate relative to healthy subjects in MRM. To our knowledge there is no study about the changes of oxidative stress markers during menstrual cyle in MRM. Our findings suggest that GSH-Rd and SOD which are important in antioxidant defence system are elevated as a reaction to oxidative stress in luteal phase of MRM. The estrogen induced changes in antioxidant defence system have to be taken into account to understand the pathophysiology of MRM and need further studies.

\section{REFERENCES}

1. Klein E., Spencer D. Migraine frequency and risk of cardiovascular disease in women. Neurology 2009; 73 (8): 42-43.

2. Headache Classification Committee of the International Headache Society (IHS). The International Classification of Headache Disorders, 3rd edition (beta version). Cephalalgia 2013; 33: 629-808.

3. Brandes JL. Migraine in women. Continuum (Minneap Minn) 2012; 18(4): 835-852.

4. Granella F, Sances G, Allais G, et al.Characteristics of menstrual and nonmenstrual attacks in women with menstrually related migraine referred to headache centers. Cephalalgia 2004; 24(9): 707-716.

5. Welch KMA, Brandes JL, Berman N. Mismatch in how estrogen modulates molecular and neuronal function may explain menstrual migraine. Neurol Sci 2006; 27(suppl 2): 190-192.

6. Martin V, Behbehani M. Ovarian hormones and migraine headache: understanding mechanisms and pathogenesis $\mathrm{V}$ part I. Headache 2006; 46(1): 3-238.

7. Geyik S, Altunısık E, Neyal AM, Taysi S. Oxidative stress and DNA damage in patients with migraine. J Headache Pain 2016; 17: 10 .

8. Deponte M. Glutathione catalysis and the reaction mechanisms of glutathione-dependent enzymes. Biochim Biophys Acta 2013; 1830 (5): 3217-3266.
9. Alp R, Selek S, Alp SI, Tașkin A, Kocyigit A. Oxidative and antioxidative balance in patients of migraine. Eur Rev Med Pharmacol Sci 2010; 14(10): 877-882.

10. Lutosławska G, Tkaczyk J, Panczenko-Kresowska B, Hübner-Woźniak E, Skierska E, Gajewski AK. Plasma TBARS, blood GSH concentrations, and erythrocyte antioxidant enzyme activities in regularly menstruating women with ovulatory and anovulatory menstrual cycles. Clin Chim Acta 2003; 331(1-2): 159-163.

11. Kato H, Sugino N, Takiguchi S, Kashida S, Nakamura Y. Roles of reactive oxygen species in the regulation of luteal function. Rev Reprod 1997; 2(2): 81-83.

12. Massafra C, Gioia D, De Felice C, Picciolini E, De Leo V, Bonifazi M, Bernabei A. Effects of estrogens and androgens on erythrocyte antioxidant superoxide dismutase, catalase and glutathione peroxidase activities during the menstrual cycle. J Endocrinol 2000; 167(3): 447-452.

13. Somerville BW. The role of estradiol withdrawal in the etiology of menstrual migraine. Neurology 1972; 22(4): 355-365.

14. Tsuda K, Kinoshita Y, Kimura Y, Nishio I, Masuyama Y. Electron paramagnetic resonance investigation on modulatory effect of 17_-estradiol on membrane fluidity of erythrocytes in postmenopausal women. ArteriosclerThromb Vasc Biol 2001; 21: 1306-1312.

15. Stirone C, Duckles SP, Krause DN. Multiple forms of estrogen receptor-alpha in cerebral blood vessels: regulation by estrogen. Am J Physiol Endocrinol Metab 2003; 284: 184-192.

16. McNeill AM, Zhang CY, Stanczyk FZ, Duckles SP, Krause DN. Estrogen increases endothelial nitric oxide synthase via estrogen receptors in rat cerebral blood vessels-effect preserved after concurrent treatment with medroxyprogesterone acetate or progesterone. Stroke 2002; 33: 1685-1691.

17. McEwen BS. The molecular and neuroanatomical basis for estrogen effects in the central nervous system. J Clin Endocrinol Metab 1999; 84: 1790- 1797.

18. Ospina JA, Krause DN, Duckles SP. 17 beta-estradiol increases ratcerebrovascular prostacyclin synthesis by elevating cyclooxygenase-1 and prostacyclin synthase. Stroke 2002; 33: 600-605. 